\title{
The Rise of Sea Level in Contemporary Times at Honaunau, Kona, Hawaii ${ }^{1}$
}

\author{
Russell A. APPle ${ }^{2}$ and Gordon A. MACDONALD ${ }^{3}$
}

\begin{abstract}
Bait cups, net-tanning tubs, and playing boards for the checker-like game of konani, which were hollowed out by the ancient Hawaiians on the surface of pahoehoe lava flows a short distance above sea level at the City of Refuge, Honaunau, Hawaii, are now submerged and unusable for their original purpose. Increased depth of water over the traditional land route used in approaching the place of refuge, comparisons of old and new photographs, and increasing storm damage to structures, also indicate a relative sinking of the shore, at a rate of about $1 \mathrm{ft}$ per century. The sinking is endangering some of the structures, and imposes a special problem in the preservation of the area. Other evidence indicates sinking of other parts of the island of Hawaii, but by less definite amounts. The rate of change of relative level of land and sea at Honaunau is much greater than that of worldwide change of sea level, and must be the result of actual sinking of the island. The logical explanation lies in isostatic adjustment resulting from loading of the earth's crust by the great added mass of the volcanoes. The southern part of the island of Hawaii appears to be sinking isostatically at a rate of about 8 or 9 inches a century.
\end{abstract}

A BY-PRODUCT of recent archeological and historical investigations at the newly established City of Refuge National Historical Park at Honaunau, Kona, Hawaii (Fig. 1) is the discovery that the coastline is sinking. A continuation of this movement will endanger valuable prehistoric and historic structures in the Park and will bring about considerable changes in the coastline. Inasmuch as the goal of the National Park Service, U. S. Department of the Interior, is to restore the scene and selected structures of this ancient Hawaiian governmental and religious center to their appearance during the late 1700 's, this threat may pose major problems to administrators of the area and restoration technicians during the next century.

The purpose of this paper is to document the rise of sea level within the last 200 years, to call attention to the problems that may arise as a result of the rise, and to suggest the probable geological explanation of the rise. The portion

\footnotetext{
${ }^{1}$ Hawaii Institute of Geophysics Contribution No. 71. Manuscript received September 9, 1964.

${ }^{2}$ Superintendent, City of Refuge National Historical Park, National Park Service, U. S. Dept. of the Interior.

${ }^{3}$ Senior Professor of Geology, University of $\mathrm{Ha}-$ waii, Honolulu.
}

of the paper dealing with historical and archeological evidence of the change is written by Apple; that dealing with geological aspects is by Macdonald.

\section{HISTORIC AND ARCHEOLOGICAL FEATURES}

It is immaterial to present and future administrators, charged with restoration and preservation of the land and structures, whether the land is sinking or the water is rising. The concern of administrators will be with the present and potential engulfment of the shore and its features, with attendant progressive changes in the location of the shoreline, as well as damages from storms and high seas in increasing areas and intensity.

Congress authorized the Park in 1955 and, after land acquisition, resident administration and establishment took place in 1961. The Park's purpose is to make its visitors understand and appreciate the history and culture of the ancient Hawaiians, and to recognize that the Hawaiian heritage is a part of the history and culture of the United States. The major interpretive theme of the Park is the concept and practice of refuge in the ancient Hawaiian civilization before 1819 


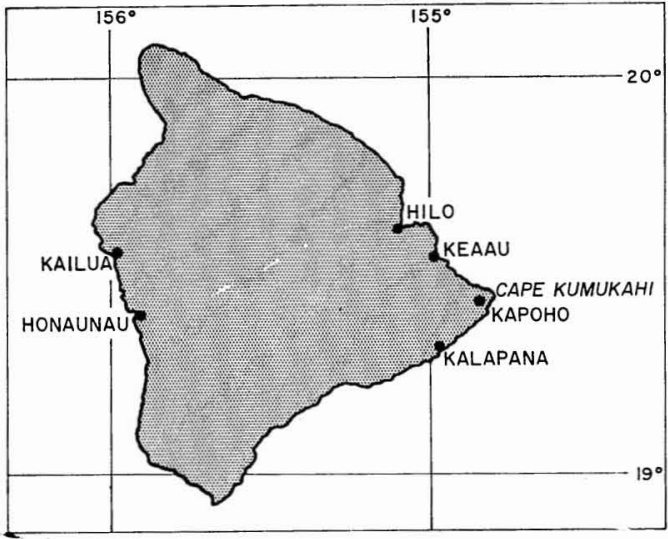

FIG. 1. Map of the island of Hawaii, showing localities referred to in text.

- a custom that so much resembled that of sanctuary in medieval Europe. Secondary interpretive themes are the rise of the Kamehameha dynasty; the transition of the Hawaiians in the Honaunau area to the present; and the Hawaiian uses of the land and sea, especially the tidal pools and adjacent offshore waters. The interpretive method is to exhibit the structures and land surfaces, restored as appropriate, which are associated with these themes. The numerous prehistoric and historic features of the area constitute exhibits-in-place.

Some of the coastal exhibits-in-place have been damaged or obliterated in whole or in part since 1823, when they were first accurately sketched, described, and/or measured by missionary William Ellis (1917:123-128). Many man-made coastal features, such as bait cups and net-tanning basins, are now under water except at extreme low tides. The shoreline of Ke-oneele cove (Fig. 2) has receded in recent years, and has cut back into the coconut grove. These and other forms of creeping engulfment portend major problems for the future in preserving the prehistoric scene and structures, even as they produce less severe problems in the present. Among the important features threatened is the dry masonry platform of the temple, Hale-oKeawe, which is in an extremely exposed position. The temple that once stood on this platform and is now scheduled for early restoration contained by 1818 the deified bones of at least 23 chiefs and kings, all of them male an- cestors or relatives of Kamehameha the Great, including one of his sons (Barrere, 1957:7080 ).

Just inland from the platform of the Hale-oKeawe is Ke-one-ele cove, beleived to be the royal canoe landing used by Kamehameha the Great in 1782, when he arrived at Honaunau in his single canoe "Noiku" to conduct state religious ceremonies. Although it was not anticipated at the time, these ceremonies marked the beginning of Kamehameha's conquest of all the Hawaiian Islands and his founding of the historic Kingdom of Hawaii (Barrere, 1957:5561; Ii, 1959:13). Photographs taken of the vicinity at Ke-one-ele cove in 1919 by members of the Bishop Museum staff show a rock rubble running between the sandy head of the cove and the platform of the Hale-o-Keawe (Bishop Museum negative 3436 , by J. F. G. Stokes). A U. S. Army Air Corps aerial photograph taken January 24, 1925 (Bishop Museum negative B2829), and a panoramic photo by Ray Jerome Baker taken between 1921 and 1925, show this rubble transformed into a neat seawall, estimated to be $6 \mathrm{ft}$ wide and $6 \mathrm{ft}$ above the sea level at the time the picture was taken. The seawall was probably built in the period 1921-24 by the County of Hawaii during the early years of its administration of the City of Refuge as a County park (Emory, 1957:35). Probably there was a local tradition, or perhaps physical evidence, that the rubble once had been a seawall. This neat seawall was very short-lived. A photograph taken by the U. S. Army Air Corps on January 25, 1926 (Bishop Museum negative 2831), shows it reduced again to rubble.

The sandy head of Ke-one-ele cove has crept inland since the 1920's, and its movement to the south was watched during high seas on January 6, 1962 (a movement that has not been restored by the building phase of the normal beach cycle). A snapshot taken by the Reverend Albert S. Baker in 1926, and a panoramic photograph by Ray Jerome Baker (no relation) at about the same time show presently identifiable coconut trees. The present waterline is close to the base of one of the trees. In about 1926 the edge of the water was an estimated 20 $\mathrm{ft}$ away. The roots of this tree, which was young in the 1920's, were protected in January, 1962 


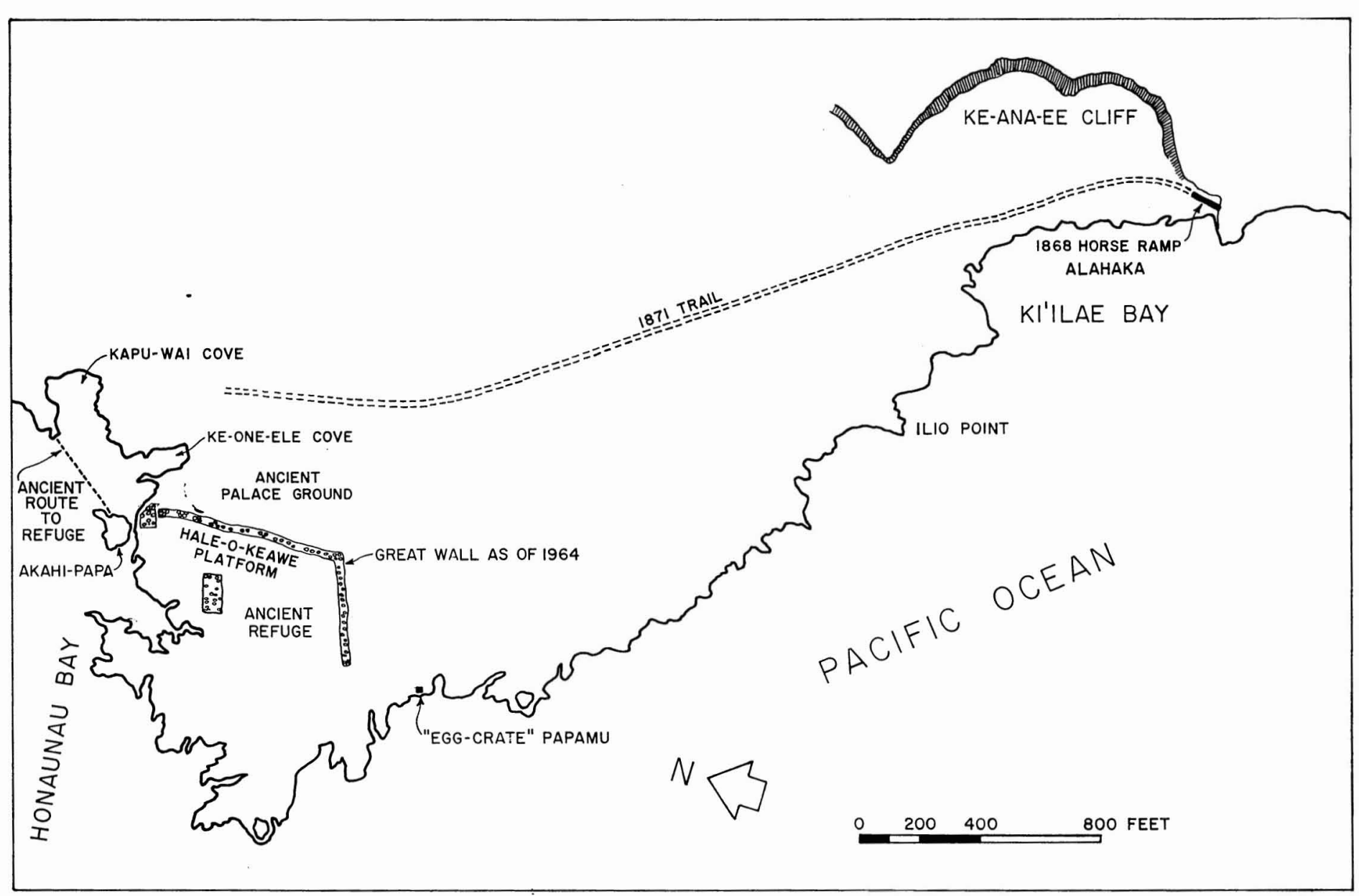

FIG. 2. Map of the Honaunau area, showing location of features referred to in text. 
only through the quick construction of a rock retaining wall to halt washout by high seas that followed the storm on January 6 . The tree is the larger one on the beach in the 1926 snapshot (Fig. 3), and the retaining wall built in 1962 is shown in a 1964 photograph (Fig. 4). On the basis of these photographs and personal conversations between Apple and Eli Carter, who was born and raised at Honaunau Bay and was the keeper of the former County park, we estimate the head of the cove has moved at least 20 feet inland since the early 1920's.

A series of photographs of a dry masonry ramp, built in 1868 to permit horses to pass along the coast up and down Ke-ana-e'e cliff (Fig. 2), indicates rapid deterioration of the ramp since 1950 (Apple, 1962: figs. 22-25).
Because of its exposed position in Ki'ilae Bay, the ramp is struck by waves during storms and high seas. Apparently the ramp stood almost intact from 1868 to 1950 , but a displacement of rocks occurred on its seaward side near the top during the intense earthquake of August, 1951 (Macdonald and Wentworth, 1951). Subsequent sea action opened and widened the damaged area so that by 1963 passage over the ramp was dangerous. The National Park Service repaired the ramp in 1963, using concealed steel reinforcements and mortar because of the frequent high wave conditions. The earthquake damage in 1951 may have been the result of more frequent wetting and lubrication of the dry masonry by splash from waves. The rapid subsequent expansion of the damaged area was

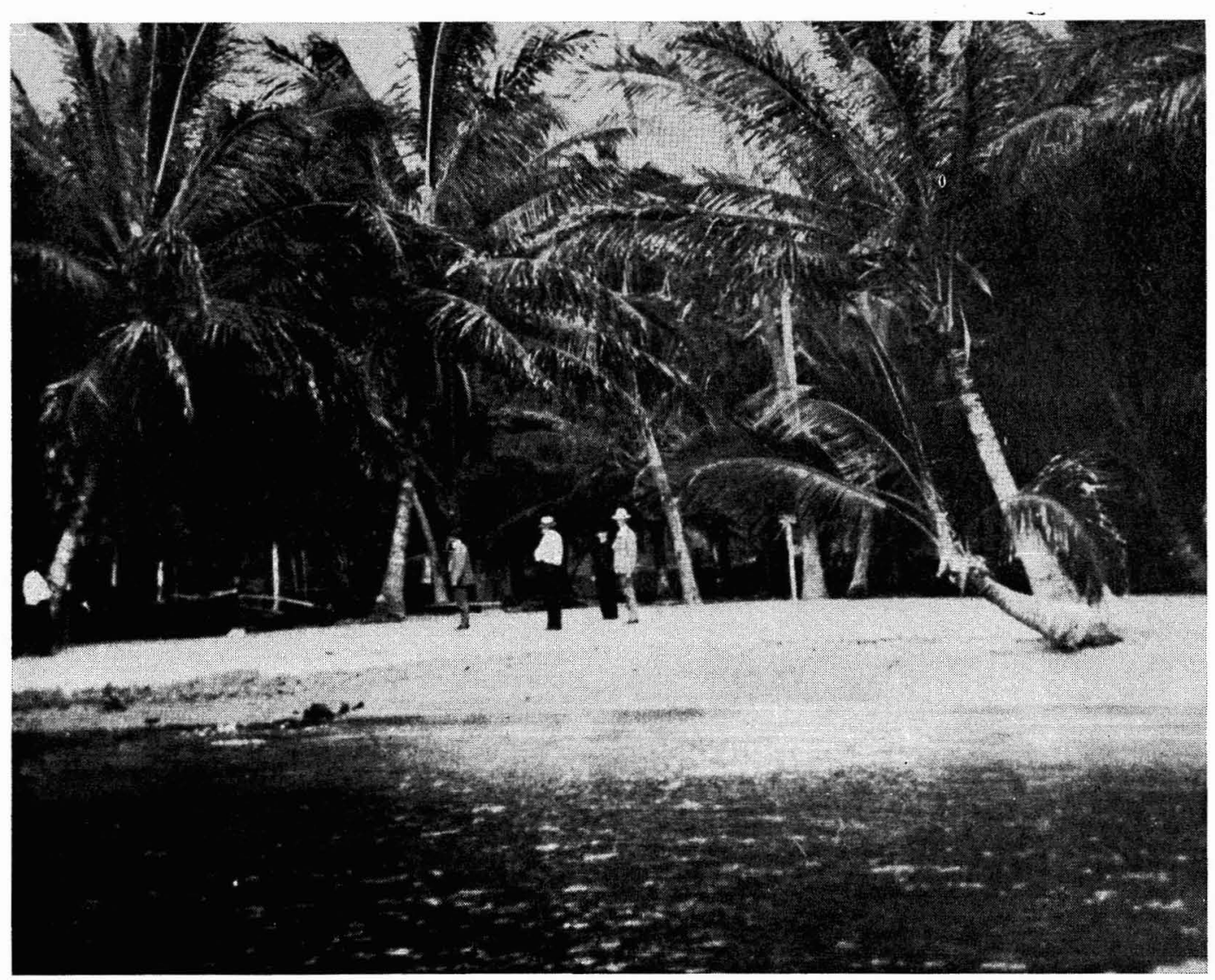

FIG. 3. Head of Ke-one-ele cove, looking south, in 1926. The larger tree on the beach is the one referred to in Figure 4. (Snapshot by Rev. A. A. Baker, courtesy of Mrs. Burton J. Loucks. City of Refuge negative 846.) 
certainly influenced by this frequent wetting during recent years. During the repair project workmen often were soaked with spray, but residents who had used the ramp in the early 1920 's do not recall any spray at that time or any concern for damage to the ramp from high seas. $^{4}$

The creeping erosion of the beach at Ke-oneele cove and the recent damage to the 1868 horse ramp are modern events. There is also expert testimony and physical evidence that the water level at Honaunau was once lower than at present.

${ }^{4}$ On-site interviews by Apple with Mrs. Mabel Keahi Alporque, April 6, 1963; with Moses Kalele, April 6, 1963; with William J. Paris, August 2, 1961; with Mrs. Martina Kaili Kekuewa Fuentevilla, July 28, 1961; and with Henry Hua, August 1, 1961.
After investigating the City of Refuge in 1919 and conducting numerous on-site interviews with long-time residents of the area, Bishop Museum anthropologist John F. G. Stokes reached the conclusion that a subsidence may have submerged certain features of ancient Hawaiian life (Stokes, 1957:199-212). Artificial concavities in the rocks which by 1919 Stokes $(1957: 199,211)$ indicated were under water at high tide, are now exposed only at low tide. Some of the concavities are pictured in Figure 5 .

Many of the artificial concavities in the lava are under water most of the time, and some are exposed only at extreme low tide. They were made by the metal-lacking prehistoric Hawaiians with hammer stones, or by abrasion with sand, stones, and pounders - a most arduous process.

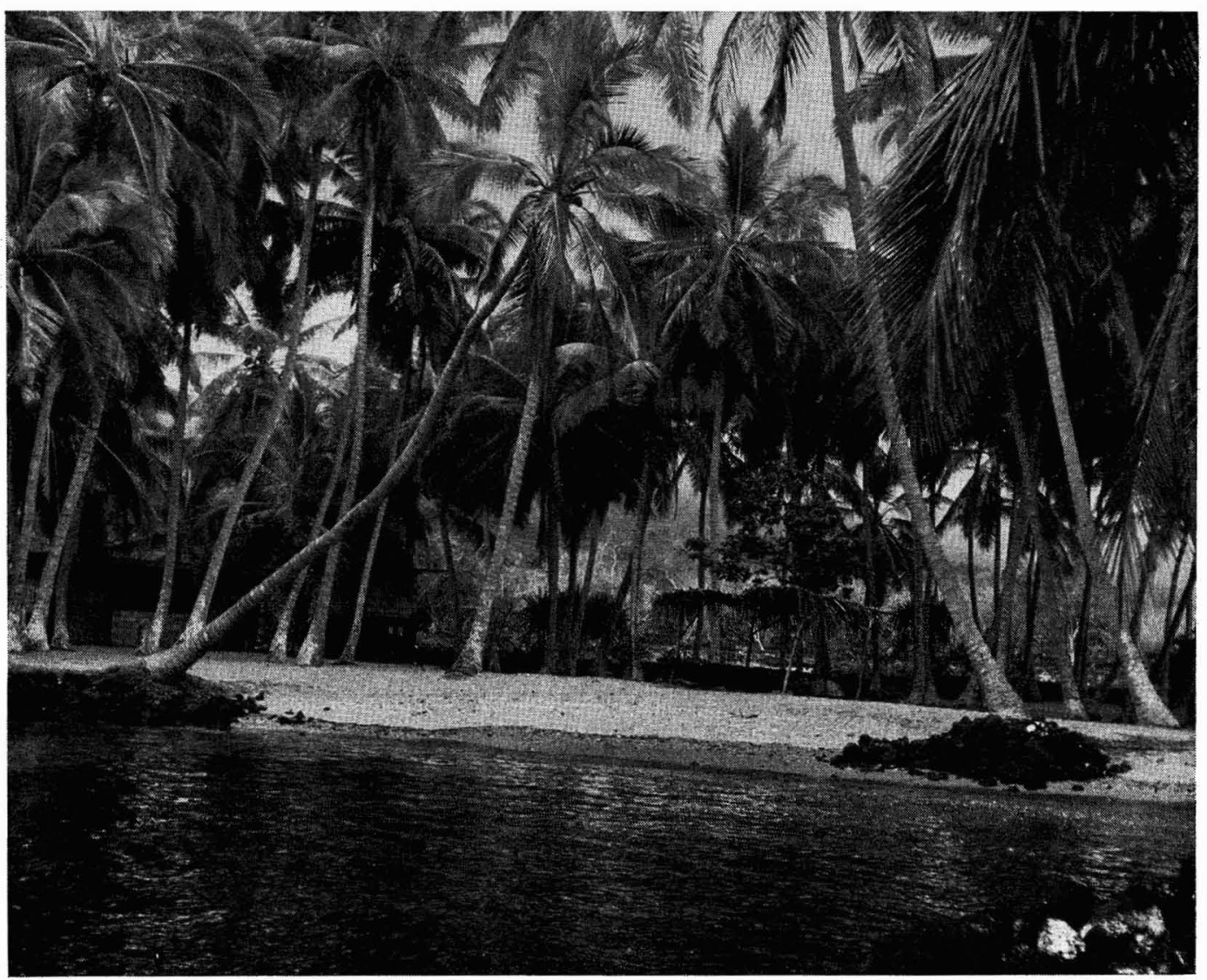

FIG. 4. Head of Ke-one-ele cove, looking south, in 1964. The base of the same coconut tree (left) shown in Figure 3 has been protected with a crude sea wall. (City of Refuge negative 1001.) 


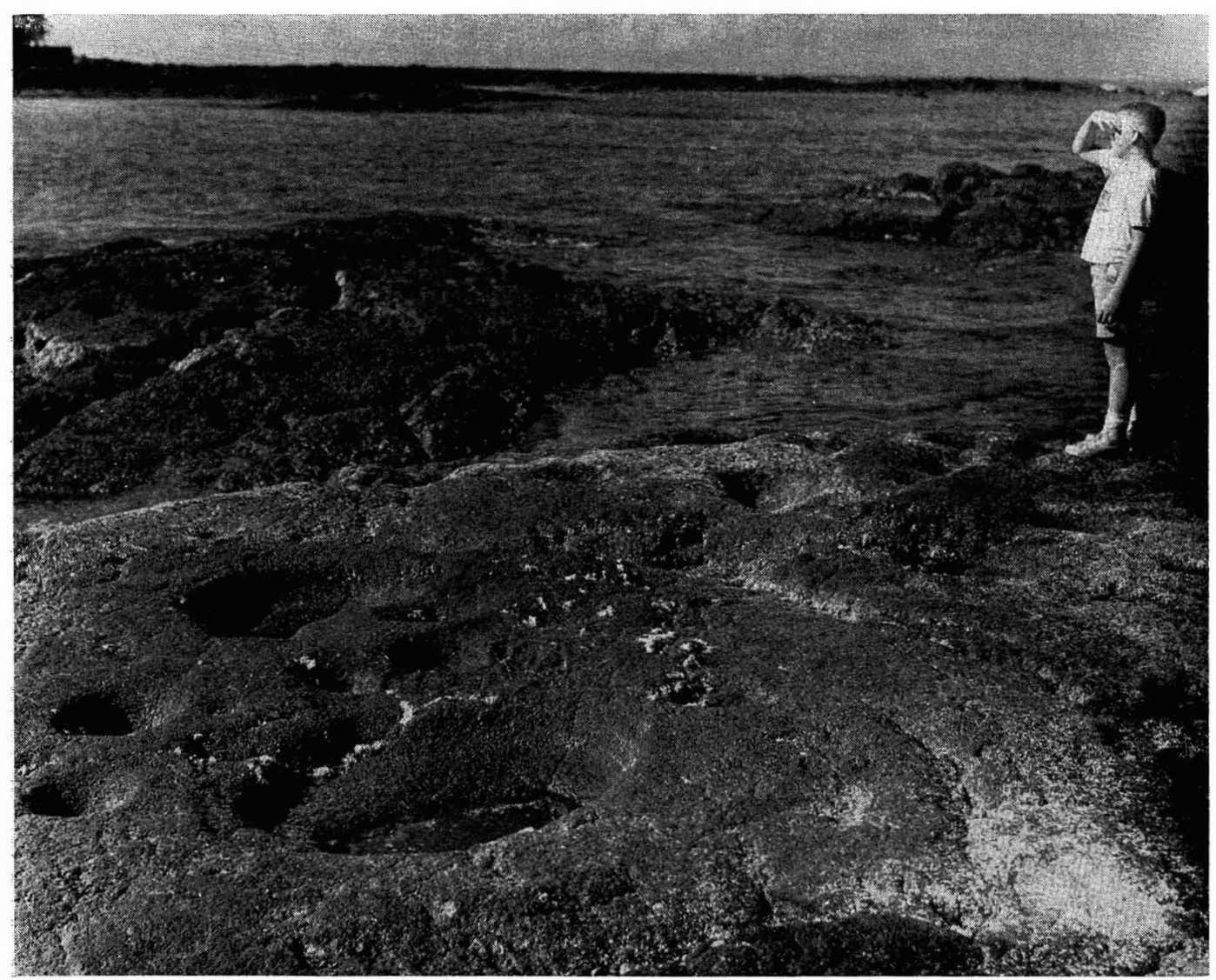

Fig. 5. Pu'u Ehu at low tide, November, 1963. This is the beginning of the ancient route through water to the refuge. The cups and basins still hold water left by the last high tide. (City of Refuge negative 1011.)

Their purposes at Honaunau Bay were described by Stokes (1957:199-200):

"Some are oval, about the size and shape of a baby's bath tub, and were used for tanning nets; others of smaller size are circular, and were mortars for pounding the tasty seaweeds; smaller ones yet were for pounding salt; while on the edge of the lava and overlooking the sea may be seen others, still smaller, for pounding crabs and sea-urchins as bauna, or chum to attract fish. . . Some large single mortars further down the coast were also used for dyeing tapa.... We must not get the idea, however, that a mortar was only used for one purpose. As it grew in size by use it would undoubtedly serve the purpose for which its size adapted it. . . The tanning tanks above ordinary high tide are still in operation."
In the Honaunau area some of the artificial concavities also held sticks which marked taboo areas or held wooden religious images. Their steep sides and depth held the sticks or images upright, and both were perhaps also lodged in upright positions by stones. Some of the image holes are now under water (Stokes, 1957:212).

At Pu'u Ehu, the northern end of the ancient route to the refuge shown in Figure 2, there are more than 40 man-made concavities, all under water except at low tide. Some of them are pictured in Figure 5. At Ilio Point (Fig. 2) there are more than 14 similar holes, also usually under water. On an underwater lava shelf west of Ilio Point, a shelf covered with marine growth and which does not show in Figure 2, an additional 29 were located during an extremely low tide in June, 1964. 
The Park's famous "egg-crate" papamu, on which the ancient Hawaiian checker-like game of konani was played, can be shown to visitors only at low tide. Figure 6 emphasizes the resemblance to a modern egg crate. In perfection of manufacture this particular papamu has few equals, and it must have been a favored gambling device of resident and visiting royalty.

According to tradition, people who used the ancient route to the refuge from the north (Fig. 2) did not get wet much above their waists, but anyone following that route today would be in water up to his neck. Dry ground was reached at the end of the water route at a lava flat named Akahipapa. In ancient times this slightly convex area, Akahipapa, was a peninsula, with water making it an island only at high tide. Today it is always an island, and during unusually high tides it is completely submerged. A human-form petroglyph on Akahipapa is frequently covered with water.

During the extremely low tides of the early daylight hours during June, 1964, an unnamed shelf in Kapu-wai cove was uncovered. Local outrigger and skiff operators had long been aware of the shelf, because it is a hazard to navigation of small craft between the cove and offshore fishing grounds. Passageway for boats lies between the northern point of the shelf and Pu'u Ehu. The Park staff took the opportunity to examine the exposed shelf in detail and map its outline and features (Fig. 7). Thirteen major, and six smaller, man-made concavities were found, all covered with marine growth. Figure 8

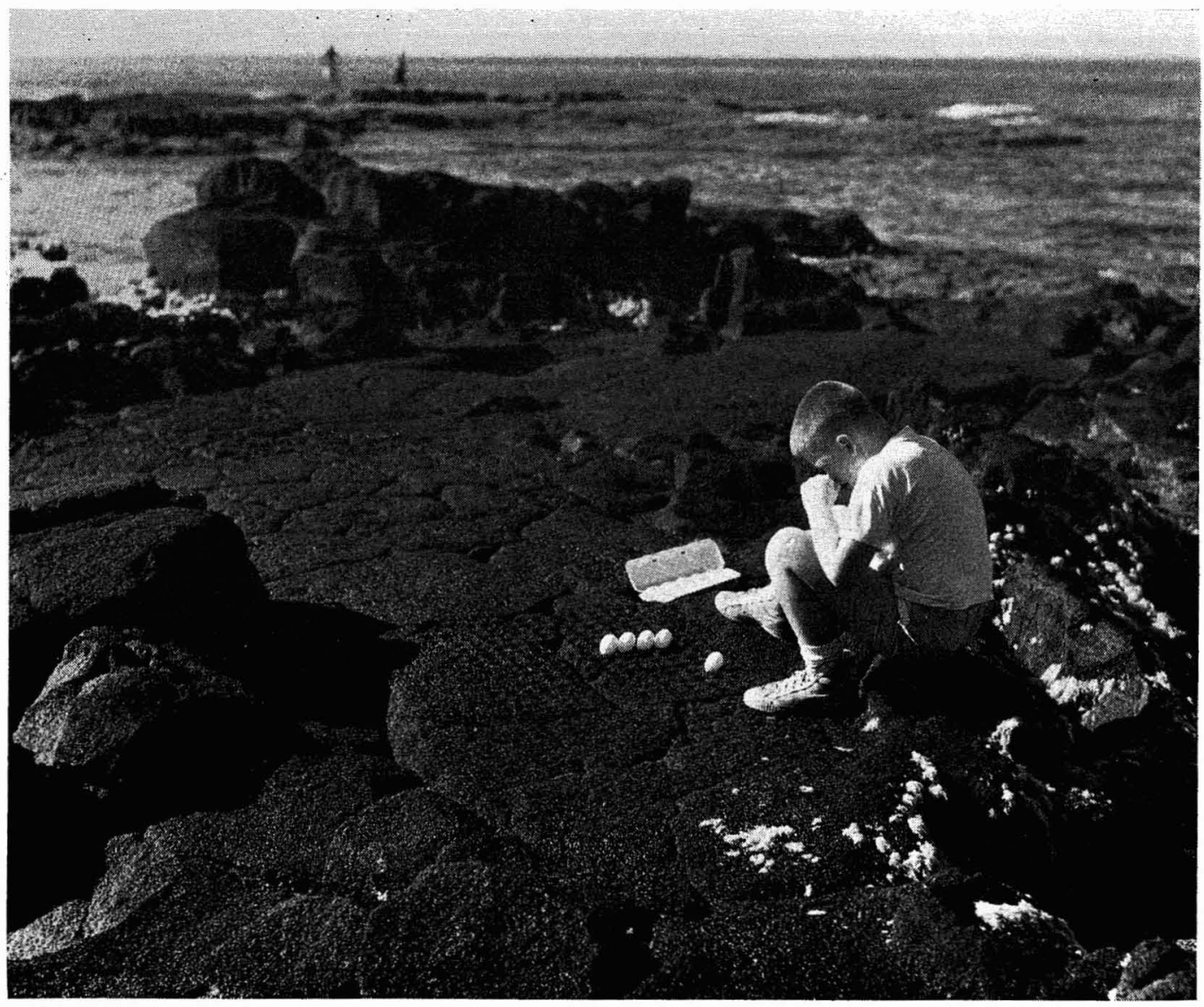

FIG. 6. "Egg crate" papamu at Paeiki, just south of the refuge, at low tide, November, 1963. (City of Refuge negative 1012.) 


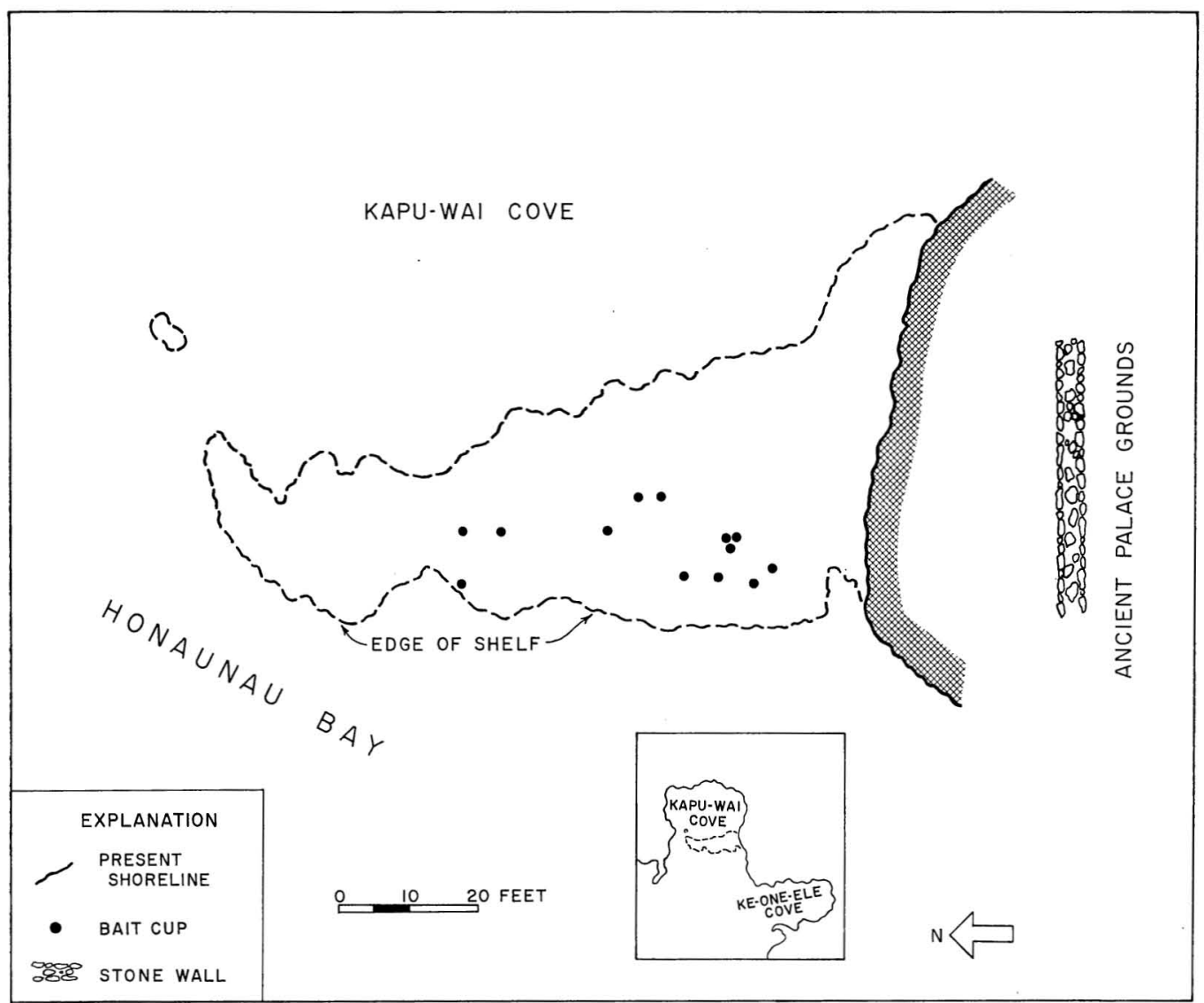

FIG. 7. Map of normally submerged marine shelf projecting from south shore of Kapu-wai cove, Honaunau Bay. (Map made by Gilbert M. Tanaka, National Park Service, U. S. Dept. of the Interior, at 8 AM, June 8, 1964.)

shows the usual present-day appearance of the shelf area, with a wave breaking over its western edge. Figure 9 shows how the exposed shelf appeared at $8 \mathrm{AM}$ on June 8, 1964.

It is significant that the shelf is unnamed. In 1919, Stokes collected place names for almost all of the minor coastal features in the area, and apparently the large shelf was not mentioned. It had been "lost" for so long that apparently its name and former uses had been forgotten by 1919.

It does not seem logical to assume that the ancient Hawaiians labored with hammer stones and pounders to abrade the artificial concavities, especially the papamu, for use only at low tide. Bait cups and tanning tubs would be useless if they were submerged. There seems to be little question that this tremendous labor went to make features on land which was normally dry, and that since the time when these features were made the land has sunk or the water level has risen.

Without a firm reference point in position and time, it is difficult to estimate the amount of rise of mean sea level relative to the land during contemporary times. Unfortunately, no surveyor set precise benchmarks in 1764 . However, we estimate that the relative rise of mean sea level during the last 200 years has been approximately $2 \mathrm{ft}$. This change helps to explain why the numerous artificial concavities are now usually under water, as well as explaining the 
inland creep of the head of Ke-one-ele cove and the wave damage to the 1868 horse ramp. A continuation of the rise will endanger other features. The head of Ke-one-ele cove may move so far inland that bridging may be required to permit access to the restored Hale-o-Keawe temple, if indeed the latter is able to survive in its exposed position. In short, it may prove difficult within the next century or two to maintain the landscape and ancient Hawaiian features as restored in place, to their likely appearance in the 1700 's.

\section{GEOLOGICAL ASPECTS}

Depression of the shoreline of the island of Hawaii relative to sea level has not been limited to the Honaunau area. Various evidences of depression have been recognized in other areas, but most of them are vague as to the amount of sinking indicated and the rate at which it is taking place.

Some sinking has been abrupt, during episodes of faulting. During historic time there have been two instances of abrupt localized sinking. During the great earthquake swarm of April, 1868 the area around Kalapana, on the southeast shore of the island (Fig. 1), sank 4-6 $\mathrm{ft}$ (Coan, 1869). In 1924, during a swarm of earthquakes on the east rift zone of Kilauea volcano, a graben (fault trough) at Kapoho, at the eastern point of the island, sank 8-12 ft, causing the drowning of coconut trees at its shoreward end (Finch, 1925). The stumps of these trees still protruded from the water in 1940.

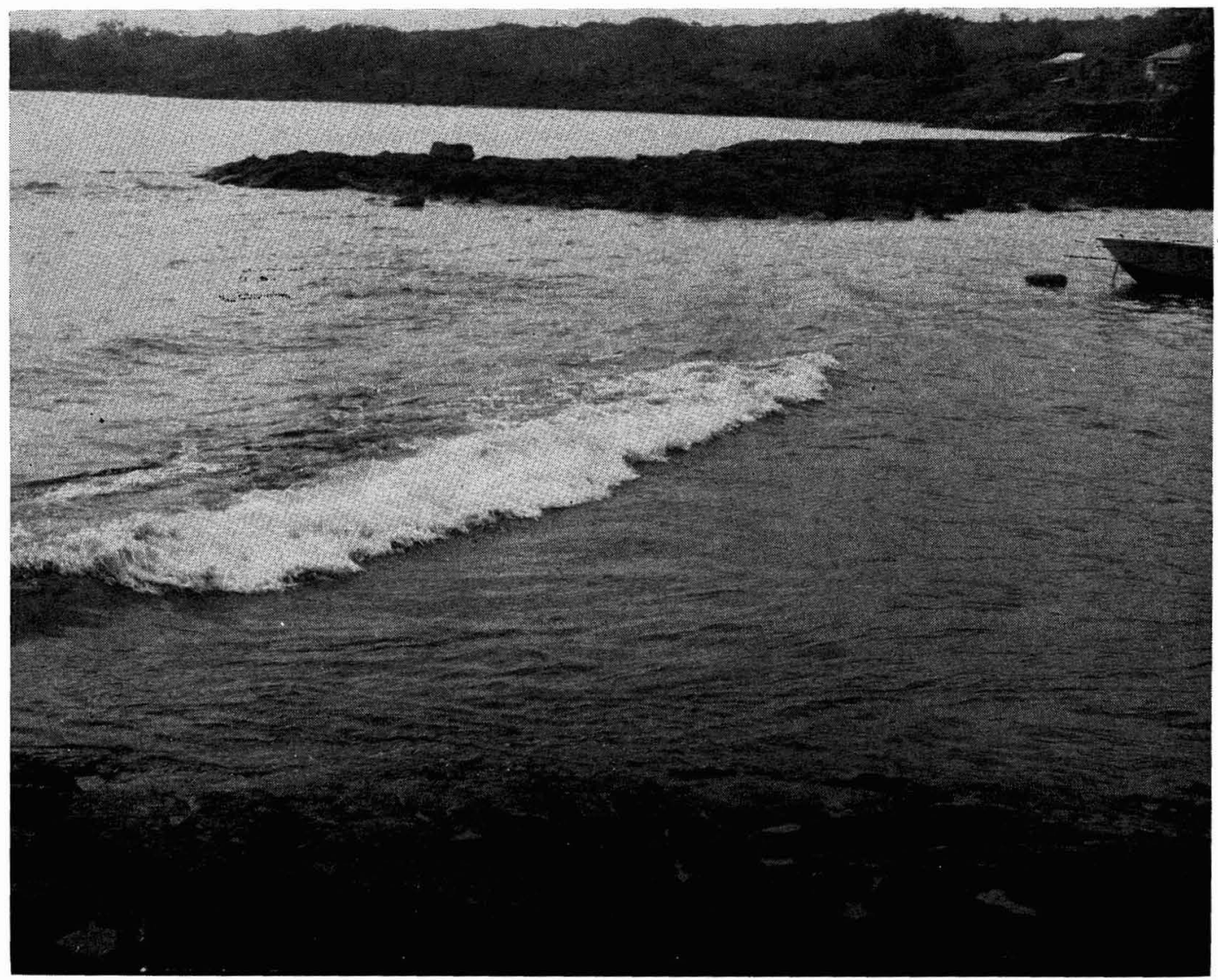

FIG. 8. Location of unnamed marine shelf shown in Figure 9, at high tide, June 8, 1964, looking north. (City of Refuge negative 1004.) 
The subsidence at Kapoho in 1924 was limited to the fault trough, a zone about 0.4 mile wide. Kalapana also lies in a graben, between two faults, and it appears probable that the sinking in 1868 was restricted largely, if not wholly, to the graben. However, other areas, not within grabens, also have sunk. Just south of Cape Kumukahi, the eastern point of the island, previous to 1960 Hawaiian fishpond walls could be seen submerged 4-6 ft deep in the ocean. (They were buried in part by the lava flow of 1960.) Judging from similar walls elsewhere, they give evidence of a sinking of at least $5 \mathrm{ft}$. The area is directly on the active east rift zone of Kilauea volcano, and it might be supposed that the sinking was localized, due to a change in volume within the eruptive core of the rift zone, a change s milar to that which produces the swell- ing and shrinking of the rift zone before and after eruptions (Macdonald and Eaton, 1964: 101). However, evidence of sinking exists also at Keaau, 14.2 miles northwest of Cape Kumukahi (Fig. 7). There, according to Eldon S. English and other members of the Shipman family, long-time owners of the property, coconut stumps are submerged below sea level and are invisible even at the lowest tides. The bases of the stumps are buried in sand, and it is difficult to determine just how deep the former ground level now lies below sea level; and also, of course, its original height above sea level is not known. Therefore, the extent of sinking is uncertain, but it must amount to several feet. The recency of sinking also is uncertain, but it appears unlikely that the coconut stumps could have survived more than a few centuries. The

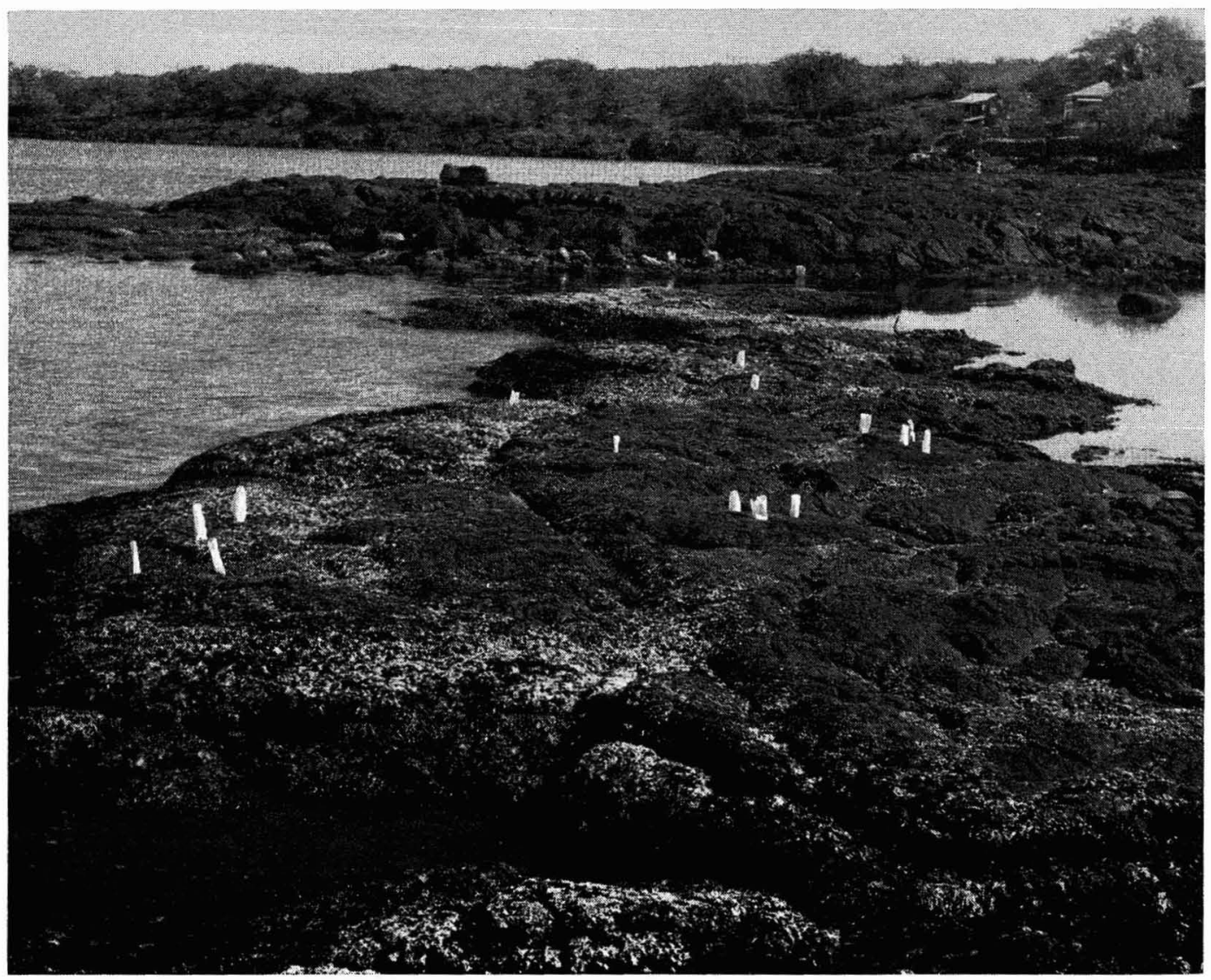

FIG. 9. Unnamed marine shelf projecting northward from the shore of Kapu-wai cove, Honaunau Bay, at low tide, June 8, 1964. Paper rolls mark some of the concavities made by ancient Hawaiians. (City of Refuge negative 1006.) 
area is far from the rift zones of either Kilauea or Mauna Loa, and both it and the Honaunau area appear to be examples of a general sinking of the island.

Thus, there is evidence of considerable recent change in the relation of land and sea along the shore of the island of Hawaii, or at least of the southern part of the island occupied by the active volcanoes. A change of this sort could conceivably be the result of either a rise of sea level or an actual sinking of the land mass, or both. A worldwide rise of sea level has indeed been taking place, but during the last century it has amounted to only about 4.5 inches (Gutenberg, 1941:729), and the average rise over the last 2,000 years has been only about 3 inches per century (Shepard, 1964). Thus the changes of roughly a foot per century at Honaunau and of several feet in the last few centuries at Keaau are three or more times as great as the rise of sea level. Most of the change must be attributed to sinking of the island.

The mechanism to explain the sinking of the island is readily available. The great pile of volcanic rocks that forms the Hawaiian ridge is a load on the earth's crust which, if the generally accepted principle of isostasy is correct, should produce a sinking of the crust and the island ridge to restore equilibrium. Seismic evidence suggests that the base of the crust is bowed down beneath the islands (Eaton and Murata, 1960 ), presumably due to this cause, and the broad trough on the sea floor adjacent to the islands has been attributed to a regional sinking of the crust to partly re-establish isostatic equilibrium (Vening Meinesz, 1940). The older, more northern islands are believed to be partly compensated isostatically (Woollard, 1951), but the island of Hawaii appears to be largely uncompensated (Goranson, 1928; Duerksen, 1943). Although the continuation of the sea floor trough around the island of Hawaii suggests that some sinking, and consequently some compensation, has in fact taken place, the stillgrowing volcanic mountains must constitute a crustal mass that is tending to sink. The actual sinking indicated by the shoreline evidence almost surely is the result of isostatic adjustment.

\section{REFERENCES}

Apple, R. A. 1965. Trails: From Steppingstones to Kerbstones. Bishop Museum Press, Honolulu. 73 pp.

BARRERE, D. B. 1957. A reconstruction of the history and functions of the Puuhonua and the Hale o Keawe at Honaunau. In: The natural and cultural history of Honaunau, Kona, Hawaii. Unpubl. manuscript, Bishop Museum, Vol. 2, pp. 38-80.

COAN, T. 1869. Notes on the recent volcanic disturbances of Hawaii. Am. J. Sci. Ser. 2, 47:89-98.

Duerksen, J. A. 1943. Gravity-anomalies and meridian deflection in Hawaii. Am. Geoph. Union Trans. 24 (Part 1) :34-39.

Eaton, J. P., and K. J. Murata. 1960. How volcanoes grow. Science 132:925-938.

Ellis, W. 1917. A Narrative of a Tour Through Hawaii in 1823. . . [Reprinted from the London edition of 1826.] Hawaiian Gazette Co., Honolulu. 442 pp.

EMORY, K. P. 1957. Honaunau in transition to the present. In: The natural and cultural history of Honaunau, Kona, Hawaii. Unpubl. manuscript, Bishop Museum, Vol. 2, pp. 3237.

FinCH, R. H. 1925. The earthquakes at Kapoho, island of Hawaii, April 1924. Seismol. Soc. Am. Bull. 15:122-127.

GoRANSON, R. W. 1928. The density of the island of Hawaii, and density distribution in the earth's crust. Am. J. Sci., Ser. 5, 16:89120.

Gutenberg, B. 1941. Changes in sea level, postglacial uplift, and mobility of the earth's interior. Geol. Soc. Am. Bull. 52:721-772.

II, JoHN PAPA. 1959. Fragments of Hawaiian History. Translated by Mary Kawena Pukui. Bishop Museum Press, Honolulu. 183 pp.

MACDONALD, G. A., and J. P. EATON. Hawaiian Volcanoes during 1955. U. S. Geol. Survey Bull. 1171. 170 pp.

_ _ and C. K. Wentworth. 1952. The Kona earthquake of August 21, 1951, and its aftershocks. Pacific Sci. 6:269-287. 
Shepard, F. P. 1964. Sea level changes in the past 6000 years: possible archeological significance. Science 143:574-576.

STOKES, J. F. G. 1957. Features pertaining to early Hawaiian life in the Honaunau Bay area. In: The natural and cultural history of Honaunau, Kona, Hawaii. Unpubl. manuscript, Bishop Museum, Vol. 2, pp. 191-212.
Vening Meinesz, F. A. 1941. Gravity over the Hawaiian Archipelago and over the Madeira area; conclusions about the earth's crust. Proc. Nederlandsche Akad. Wetensia 44(1):2-12.

WOOLlard, G. P. 1951. A gravity reconnaissance of the island of Oahu. Am. Geoph. Union Trans. 32:358-368. 